Essays in Regional Economics 

Benjamin Chinitz

William Alonso

Gerald Kraft

Alan R. Willens

John B. Kaler

Daniel Shimshoni

Roger E. Bolton

William H. Miernyk

George H. Borts

Mahlon R. Straszheim

Joseph J. Persky

Stanley L. Engerman

J. W. Milliman

James C. Burrows

Charles E. Metcalf

\section{Essays in Regional Economics}

Edited by John F. Kain and John R. Meyer 
(C) Copyright 1971 by the President and Fellows of Harvard College

All rights reserved

Library of Congress Catalog Card Number 73-160024

SBN 674-265-629

Printed in the United States of America 